\title{
Nå må det virkelig gjøres noe, og det med en eneste gang
}

\author{
Hvis noen blir syke, må de behandles. Helst med en gang, for ikke å risikere farlige situa- \\ sjoner for pasienten. Men mye tyder på at det nå skjer en massiv ressurssløsing på grunn \\ av overbehandling.
}

I en rapport fra Kunnskapssenteret fastslås det blant annet at pasientbehandling viser svære regionale forskjeller - uten at forekomsten av en sykdom varierer $(1,2)$. Olav Helge Førde ved Universitetet i Troms $\varnothing$ sier det slik: Troen på at mer helsetjeneste er bedre enn mindre, er svært inngrodd (1).

I Helse Vest ble det nylig slått alarm. På grunn av lange, lange helsekøer har hele foretaket tatt et krafttak. Ventelistene er kortet ned, og flere og flere får den rettmessige behandlingen de venter på. Men så viser det seg at mange pasienter møter ikke opp når de har fått sykehusplass. En hærskare av helsepersonell står i døren og venter (3). Resultatet er at vi snart må sette opp ventelister for helsepersonalet i stedet for pasientene. Kanskje er mange av dem som har presset på for å komme foran i helsekøen, ikke så syke likevel. Eller motsatt: Det kan ha skjedd noe med dem i mellomtiden.

Den norske filosofen og psykologen Ole Jacob Madsen tar i boken Vår terapeutiske kultur (4) et oppgjør med hele grunnlaget som vi bygger psykologisk og medisinsk behandling på. Han er gått til angrep på det vi kan kalle den politiske korrekthet i omsorgskulturen som gjennomsyrer hele samfunnet vårt. I boken viser han til at markedsliberalismen legger et større og større ansvar på enkeltpersonen, slik at de selv må ta avgjørelsen om hva som er sykt og hva som skal behandles. Helsevesenets omsorgskultur og plikt til å sørge for terapi kan deretter føre til at helsetilbudene blir den rene shoppingfesten. Han viser til advarsler fra samfunnsforskere om den massive påvirkningen til sunn livsstil som både helsevesenet, apotek- og reklamebransjen kommer med. Han spør også om det er blitt etablert en usunn diagnostiserings- og behandlingsiver der vi behandler langt flere, men på svakere grunnlag enn før. Generelt blir flere og flere normaltilstander definert som sykdom.
Da er det viktig å minne om hva klinisk psykolog, psykoanalytiker og dr.philos. Torberg Foss skrev for snart to tiår siden. I 1994 presenterte Foss en tankevekkende artikkel i Tidsskriftet. Her filosoferer han over det som kalles lidenskapen etter å helbrede, eller furor sanandi. Han påviser at personlige lidenskaper hos helsepersonalet kan blande seg inn i ønskene om å kurere pasienter. Artikkelen var langt forut for sin tid, og nå er den toppaktuell. Hovedspørsmålet, som jeg tiltrer fullt ut, er om vi har mistet noe av ydmykheten i arbeidet med pasienten. En viktig konsekvens blir at furor sanandi er en sykdom hos terapeuten og ikke hos pasienten, men det er sistnevnte som må bære alle lidelsene forbundet med dette alvorlige syndromet. Man kan bli syk av mindre.

\section{Ole Didrik Lærum}

ole.laerum@gades.uib.no

Ole Didrik Lærum er professor (adj.) ved Københavns Universitet og professor emeritus ved Universitetet i Bergen.

\section{Litteratur}

1. Storvik AG. Ny rapport avdekker omfanget av overbehandling. Dagens Medisin 15.8.2013. www.dagensmedisin.no/nyheter/ny-rapport-avdekker-omfang-avoverbehandling/ (23.9.2013).

2. Haugum M, Bjertnæs $\emptyset \mathrm{A}$, Iversen $\mathrm{HH}$ et al. Commonwealth Fund-undersøkelse blant allmennleger i 10 land: norske resultater i 2012 og utvikling siden 2009. Rapport nr. 11/2012. Oslo: Kunnskapssenteret, 2012. www.kunnskapssenteret.no/publikasjoner/commonwealth-fund-unders\%C3\%B8kelse-blantallmennleger-i-10-land-norske-resultater-i-2012-og-utvikling-siden-2009 (23.9.2013).

3. Steiro G. Den friske pasienten. Kommentar. Bergens Tidende 2.7.2013.

4. Madsen OJ. Den terapeutiske kultur. Oslo: Universitetsforlaget, 2010.

\section{Furor sanandi \\ en refleksjon over lidenskapen etter å helbrede}

Foss T. Furor sanandi- en refleksjon over lidenskapen etter å helbrede. Tidsskr Nor Lægeforen 1994; 114: $723-5$.

\begin{abstract}
I form av et essay, presenterer psykolog Torberg Foss en fenomenologisk studie av begrepet furor sanandi.
\end{abstract}

Kan personlige lidenskaper blande seg inn i vårt ønske om å kurere pasienter, og er vi i så fall mindre oppmerksomme på en slik motivasjon i dag enn tidligere?

Forfatteren diskuterer om vi har mistet noe av ydmykheten i vårt arbeid med pasientene, i og med fremveksten og troen på de biologiske vitenskaper. Begreper som helse og helbredelse droftes i lys av disse spørsmålene.

\section{En formaning fra det 17. århundre} Den lidenskapen jeg her skal drøfte, kan i første omgang være vanskelig å få øye på i den kliniske hverdag. Skal furor sanandi bli en mer gjenkjennelig figur for oss, er det derfor nødvendig å ta en omvei.
Den kan gå via Ambroise Paré, en fransk anatom og kirurg som levde på 1600-tallet. Han burde huskes for å ha sagt: Je le pansay, Dieu le guarit - jeg lindrer, Gud helbreder.

«Je le pansay», en mer presis oversettelse ville være «Jeg forbinder». Nå er det imidlertid ikke oversettelsen fra fransk til norsk jeg skal ta for meg. Av langt større interesse, er problemer forbundet med en annen 
oversettelse: Hvordan lar dette sitatet fra det 17. århundre seg oversette til vår tid? I hvilken grad er den besinnelse som ligger i Parés utsagn, hørbar på slutten av det 20. århundre?

\section{Begjæret etter å helbrede}

Med denne problemstillingen som bakgrunn, skulle nå furor sanandi kunne tre frem som en mer synlig figur. Selve uttrykket - furor sanandi - altså raseriet eller lidenskapen etter å helbrede har som Parés ord preg av en annen tid. Jeg ble selv overrumplet da denne lidenskapen første gangen ble pekt ut for meg. Det skjedde i samtale med en eldre fransk psykoanalytiker: «Hvis et ønske om å støtte, oppmuntre, eller hjelpe dukker opp i Dem, skal De ta Dem i akt. Det kan da være noe fra Deres egen person som griper forstyrrende inn.»

Fortsatt kan jeg stusse over denne påpekingen, nærmest som om en eller annen anretning fra tidligere tider var blitt stilt frem foran meg. For strider ikke denne påpekingen imot de verdier som er viktige for oss i dag, i det hele tatt mot det som faller oss naturlig? Man kunne nettopp innvende at det som ligger i dette såkalte vanviddet, ikke er annet enn viljen til å gjøre en god jobb, det være seg som lege eller psykolog.

Nå bør det skytes inn at det nok ikke var den franske analytikers hensikt å frakjenne terapeuten enhver form for menneskelighet. Han ville ha frem hvordan en terapeutisk iver kan gjøre en mindre lydhør for hva pasienten har på hjerte.

\section{Hysterikeren og legen}

Så skulle det nå likevel være noe verdifullt som er blitt brakt til torgs med innsikten i denne lidenskapen? I så fall kan ikke psykoanalysen påberope seg æren alene. Den må bl.a. deles med Jean-Marie Charcot, berømt for sine spektakulære presentasjoner av hysteriske kvinner i Paris på slutten av forrige århundre, som så vel Freud som vår egen Bjørnstjerne Bjørnson skal ha overvært.

Mindre kjent er Charcot for fremheving av en annen form for lidelse, denne gangen hos sine kolleger, kirurgene. Denne mania operativa aktiva kunne slå ut nettopp i møtet med den hysteriske kvinnen (1). Etter å ha palpert ovariene og uterus, etter å ha eksplorert vagina; med andre ord etter gjentatte og mislykkede møter mellom lege og pasient, griper kirurgen etter kniven. For Charcot var furor sanandi langt synligere hos kirurgen.

Spørsmålet er nå om kirurgen er så alene med denne lidenskapen. For å finne ut det kan man begynne med å spørre hva det var som provoserte kirurgen. Var det noe mer enn denne vedvarende klagingen?
I alle de hysteriske symptomene, uansett deres forskjellige utforming, synes det å være en gjennomgående dimensjon. De er alle på en eller annen måte knyttet til mangler, det være seg i form av forbigående lammelser, som bortfall av følsomhet, midlertidig døvhet eller blindhet. Frigiditet føyer seg inn i denne rekken. Alle symptomene, uansett hvor de måtte befinne seg på kroppen, eller hvilken form de nå har, lar seg alle oversette til: Jeg er ikke komplett.

\section{Helbredelse av mangler}

La oss nå forlate hysterikeren, visstnok byr det på problemer å gjenfinne også henne $i$ vår tid, og heller vende tilbake til den kliniske hverdag. Hva gjør vi med de mangler vi blir eksponert for? Å utbedre dem, eller utfylle dem er nærliggende. Men dermed bør vel problemet omkring furor sanandi også stilles oss selv.

Å helbrede er å hele, å gjøre hel. Altså en tilsynelatende naturlig holdning overfor symptomer som har mangler som et gjennomgående aspekt. Det å gjøre den andre hel kan i neste omgang ta form av det å skulle gi det den andre mangler; et ytterligere skritt vil være å være det den andre mangler. At pasienten forestiller seg helbredelse, nettopp som det å få det en mangler, kan også tilspisse forholdet mellom behandler og pasient. På en eller annen måte kan behandleren med sin egen personlighet som innsats, inngå i det å skulle gjøre den andre hel.

Slik kan det å helbrede bli en svært ladet situasjon der behandleren kan hente sin affekt utenfor det profesjonelle liv. La meg bare, i forbindelse med dette ønsket om å gjøre komplett, minne om en tilsvarende situasjon, knyttet til det infantile eller det ubevisste: barnets bestrebelser på å gjøre sin mor komplett; med gaver eller seg selv, å søke å rå bot for en eller annen emosjonell tilbakeholdenhet hos henne. Poenget er å antyde hvilke følelser som kan komme over oss i vårt forsøk på å hele.

At disse følelsene kan få en temperatur som gjør oss nærmest forrykte, altså et helbredelsesvanvidd, kan forstås ut fra det faktum at ingen av oss er hele. Tvertimot, vi er halve vesener, ett kjønn er alt hva vi har, og i våre liv minnes vi stadig på at vi en gang skal dø. Å skulle gjøre hel tegner seg da som en umulig oppgave, og hva kan det ende med om man setter seg noe umulig fore?

\section{Hva kan mistes om man blir frisk?}

Det er verdt å stanse opp ved dette begrepet om helbredelse. Det har nesten noe gammelmodig ved seg. Ordet har nærmest gått ut av bruk eller av mote innenfor medisinen og heller blitt overlatt andre. Innenfor alternativ medisin bedriver man derimot fortsatt med helbredelse, for ikke å snakke om healeren, han står og faller med det.

Legen er derimot ikke lenger så avhengig av å skulle helbrede. Men selv om ordet er lite i bruk, skulle man formode at det var et fundament for den kliniske virksomheten. Interessant er det da å merke seg tausheten som omgir ordet helbredelse, nesten som en ikke vedstått ambisjon.

Det er også bemerkelsesverdig lite refleksjon over hva som skulle ligge i det å bli helbredet. Man tar det for gitt at det å bli frisk er bra; det er noe alle ønsker. I mange tilfeller kan det ikke råde så stor tvil heller; det helbredede menneske, gjenforent med sin familie eller venner har nådd en ønskverdig tilstand.

Likefullt kan man spørre hva vil det egentlig si å bli helbredet. «Å bli frisk, hva er nå det,» var det en pasient på divanen som undret seg. Og han fortsatte; «å bli frisk er som å få besøk av min fetter fra landet. Ikke var det helt ventet, og ikke var det lett å få frem den store entusiasme heller. Men plutselig, så stod han nå bare der i døren.»

Helt gitt er det altså ikke hvordan man hilser det å bli frisk. Det er flere som regner inn et tap i et helbredende forløp. En måte å tematisere dette tapet på er gjennom begrepet sykdomsgevinst. Men enten man nå tenker det som primær- eller sekundærgevinst, så har en slik modell ved siden av å være altfor velbrukt, også andre begrensninger. Det viser seg særlig når man står overfor psykiske symptomer og de vansker en pasient kan ha med å skille seg fra dem, gjennom å bli helbredet. At en pasient skulle nøle med å slippe tak i sine plagsomme symptomer, er en merkelig tanke, men likefullt en gjengs erfaring, skulle jeg tro.

I forbindelse med en behandling av en tvangsneurotiker med en svært rikholdig symptomdanning, hevdet Freud: Det meste av denne pasientens seksualliv, er å finne $i$ hans symptomer (2). I sannhet en dristig formulering, men i så fall, kan den gi en innfallsvinkel til å forstå hvorfor man kan nøle med å oppgi sine symptomer? I det å bli helbredet må det ifølge et slikt perspektiv ligge en renonsering på en særskilt form for tilfredsstillelse.

En annen grunn til å skulle holde fast på sine symptomer, ligger i at de kan forstås som pasientens eget forsøk på å helbrede seg selv. Med angst eller depresjon, kan jeget hos den enkelte forsøke å takle en dyp, ubevisst smerte. Dette kan være et nyttig perspektiv å ha med seg, om man opplever at en pasient kjæler med sine symptomer. Symptomene vil da være en buffer mot en overveldelse eller et sammenbrudd, og dermed kan de være noe en pasient rett og slett trenger for en tid. 
Disse perspektivene på symptomet kan være med å gjøre helbredelse til et mer problematisk begrep. Likeledes begrepet om helse som et ubetinget gode. En slik problematisering skjer når helse oppfattes som organenes taushet. Denne definisjonen stammer ikke fra en luftig filosof, men fra kirurgen René Leriche (3), altså en mann med et mer håndfast grep om vårt indre.

Organenes taushet... Mine assosiasjoner går til den helbredede hysteriker, eller skulle jeg kanskje si den forsvunne hysteriker. Hun som endelig lyktes i å komme under kirurgens kniv, det være seg hysterektomi eller en tilsvarende drastisk måte å bli av med sine kroppslige symptomer. De som har truffet henne, kan sikkert bekrefte hvordan avstumpetheten kunne bre seg til hennes emosjonelle liv. Ikke bare hennes livmor var falt til ro.

Eller tenk på pasienten med den kurerte spiseforstyrrelse, symptomene er borte og man sitter alene igjen. Det kan i alle fall være fruktbart å regne inn at det kan ligge et tap i det å bli helbredet. For man blir ikke bare befridd for et fremmedlegeme. Det man kan miste, kan være noe verdifullt, den del av en selv som er den mest relasjonelle. At det var gjennom symptomet vi påkalte verden, og det er gjennom symptomet den svarer oss (4).

Dette sistnevnte perspektivet er vel særlig blitt videreutviklet gjennom familieterapien. Men aktelsen for symptomet har vi fra den klassiske psykoanalyse, hvor symptomet verdsettes som det ubevisstes munn. Gjennom symptomet meddeles vi det som er vanskelig å si på en annen måte, og låner vi øre til det, kan behandlingen starte.

Akkurat dette poenget kan kanskje bli tydeligere om det stilles opp mot alle de krigs- metaforene vi bruker når vi skal beskrive sykdom og helbredelse. Sykdom er gjerne noe vi blir angrepet av. Motstanden kan ha vært nedsatt. Behandlingsstrategier settes opp, slik at sykdommen kan bekjempes.

Noen ganger kan denne kampen forflytte seg fra sykdom til pasient. For hvem av oss har ikke erfart hvordan forholdet til pasienten nettopp kan ta form av en kamp. Da kan det være nyttig å minne seg om at pasienten ikke bare er en som har en sykdom, men også en som er syk. Med andre ord kan det å være syk, tenkes på som en spesiell livsform, som det gjelder å ha en viss aktelse for, om man skal unngå å komme på kollisjonskurs med pasienten. Hør bare på Marcel Proust, som kjente medisinen fra vrangsiden: Sykdommen er den mest respekterte av alle leger: til den omsorgsfulle og den sakkyndige gir man bare løfter, smerten adlyder man (5).

Respekten for legen har åpenbart sin grense, når sykdommen tilskrives en slik autoritet. I dette perspektivet ligger det mer i det å være syk enn kroppslige lyter. Det er nærmest som man her hos Proust aner spor av et religiøst liv.

Og det er jo påfallende $i$ vår tid hvordan køene på legekontorene kan være ekstra lange på mandager, mens besøkstallet i kirken dagen forut har vært for nedadgående. Med dette vil jeg ikke antyde en årsaksmessig sammenheng, men heller gi et bilde som kan sette dagens store etterspørsel etter helse i relieff (6).

\section{Jeg lindrer, Gud helbreder}

Dette sitatet fra Proust bringer oss tilbake til Ambroise Paré. Jeg lot hans uttalelse jeg lindrer, Gud helbreder - være en slags ledetråd, som jeg har forsøkt trekke med inn i vår tid. En av de store forandringer som har inntruffet siden ham, er fremveksten av vitenskapene. Universet og tenkningen har dermed forandret seg.

Faren for å bli polemisk ville være overhengende, om jeg nå foreslo en ny oversettelse, mer i pakt med vår tidsånd: jeg lindrer, vitenskapene helbreder, eller i det minste, vitenskapene vil en dag helbrede.

Spørsmålet gjenstår imidlertid om Parés besinnelse vil være hørbar i dag, i en tid hvor man knapt tar ørens lyd for ord som kvalitetssikring og produktkontroll. Og om hans ord skulle nå oss, kan de få oss til å besinne oss i våre forventninger til hvilke svar vitenskap kan bringe oss, i dag eller i fremtiden.

I kjølvannet av fremveksten av vitenskapene, kan vi ha glemt hva som står på spill i det å være syk og be om hjelp. For hva kan Ambroise Paré ha tenkt der han stod bøyd over sine lik? Kanskje at sjelen må være av et annet stoff.

Torberg Foss Psykologisk klinikk I Psykologisk institutt Universitetet i Oslo Postboks 1094 Blindern 0317 Oslo

Litteratur

1. Israël L. L'hysterique, le sexe, et le médecin. Paris: Masson, 1983.

2. Freud S. Bemerkungen üiber einen Fall von Zwangsneurosen. Frankfurt am Main: Fische Studienausgabe, 1972.

3. Canguilhem G. Une pédagogie de la guérison. Nouvelle Revue de Psychanalyse 1978: 17: 13-27.

4. Lavie J-C. Guerir de quoi? Nouvelle Revue de Psychanalyse 1978; 17: 187-201.

5. Proust M. På sporet av den tapte tid, 8. Oslo: Gyldendal, 1988

6. Foss T. Psykoanalysens hemmelighet. Oslo: Tiden 1990 